\title{
A new species of Uvariopsis (Annonaceae), endemic to the Eastern Arc Mountains of Tanzania
}

\author{
Th.L.P. Couvreur ${ }^{1}$, W.R.Q. Luke ${ }^{2}$
}

\section{Key words}

Annonaceae

endemism

IUCN conservation status

monoecy

taxonomy

Udzungwa Mountains

Usambara Mountains

\begin{abstract}
The Eastern Arc Mountains of Tanzania enclose high levels of plant and animal diversity with many yet to be described species. Here we describe a new species of the pan-tropical plant family Annonaceae named Uvariopsis lovettiana. It closely resembles another Eastern Arc endemic species, U. bisexualis, and its possible relationships with this species are discussed. A description with illustrations is presented as well as a suggestion for the IUCN conservation status of this new taxon.
\end{abstract}

Published on 16 April 2010

\section{INTRODUCTION}

The Eastern Arc Mountains of Tanzania and Kenya are a chain of 13 ancient mountains stretching from southern Kenya to south-central Tanzania (Lovett 1993). The isolation, age and high degree of forest fragmentation in these mountains have combined to produce outstanding levels of biodiversity and high levels of endemism in both animals and plants, earning them the status of biodiversity hotspot (Lovett 1993, Myers et al. 2000, Burgess et al. 2007). Within the Eastern Arc Mountains, the Udzungwa Mountains stand out as having the largest cover of rain forest $\left(1350 \mathrm{~km}^{2}\right)$ supporting the highest number of endemic vertebrates and the second highest for plant endemics per $\mathrm{km}^{2}$ (Burgess et al. 2007). Yet, the biodiversity of the Udzungwa Mountains is still poorly known, with numerous new species of animals and plants being regularly described. Recently, two new mammal species (the highland mangabey, Lophocebus kipunji (Jones et al. 2005) and the Udzungwa elephant shrew, Rhynchocyon udzungwensis (Rovero et al. 2008)) and a new slug genus (Verdcourt 2003) were described from the Udzungwa Mountains stressing once again the biological importance of this region as well as showing how little we know from these forests. The new species described here adds up to the list of c. 70 known endemic or near endemic tree species from the Eastern Arc Mountains (Burgess et al. 2007) and increases the list of new plants described recently from the Udzungwa range (Luke \& Beentje 2003, Knox et al. 2004, Luke \& Deroin 2005).

Uvariopsis is a strictly African genus of 17 known species belonging to the Annonaceae (Magnoliales), a pan-tropical family of trees, shrubs and lianas with c. 120 genera and c. 2500 species (Chatrou et al. 2004). Uvariopsis is one of the rare genera in which monoecious flowers occur within this generally bisexual family (Van Heusden 1992). Within Uvariopsis only U. bisexualis

\footnotetext{
${ }^{1}$ Netherlands Centre for Biodiversity Naturalis (section NHN), Biosystematics Group, Wageningen University, Generaal Foulkesweg 37, 6703 BL Wageningen, the Netherlands; corresponding author e-mail: tcouvreur@nybg.org.

2 East African Herbarium, National Museums of Kenya, P.O. Box 40658, Nairobi, Kenya; Centre for Tropical Plant Conservation, Fairchild Tropical Botanic Garden, 11935 Old Cutler Road, Coral Gables, FL 33156-4242 USA.
}

Verdc. (Verdcourt 1986) and U. tripetala (Kenfack et al. 2003) have bisexual flowers. Additionally, Uvariopsis deviates from the typical trimerous floral structure found in Annonaceae flowers ( 3 sepals, and 2 whorls of three petals) in having 2 sepals and one whorl of 4 petals (except for $U$. tripetala with 3 sepals and 3 petals and $U$. congolana with 2 sepals and 3 petals). Most of the species are found in lowland or montane rain forests of Lower Guinea and the Congolian basin with just two species occurring in Upper Guinea and three in East Africa (Kenfack et al. 2003) and at least one still remains to be described from Kenya.

A molecular phylogenetic study of the Annonaceae (Couvreur et al. 2008) indicated that Uvariopsis clustered within the so-called 'long-branch clade' (LBC, Richardson et al. 2004), one of the two major clades identified in the family. Within the LBC, Uvariopsis was nested in a large clade of African genera (Couvreur et al. 2008) and was recovered as sister to the panAfrican genus Uvariodendron. This African clade of 12 genera is characterized by tetrad pollen grains and sessile monocarps (Couvreur et al. 2008).

\section{MATERIALS AND METHODS}

\section{Morphology}

This study is based on specimens from the DSM, MO and WAG herbaria. For one collection spirit material was also available (Couvreur 97b, WAG).

\section{Conservation status}

In absence of detailed population information, it has been shown that herbarium collections constitute a valuable source of data and can be used to determine categories of threat using criterion B (Schatz 2002, Willis et al. 2003). The software ArcView v3.3 (ESRI 2002) was used to produce the distribution map. The add-in script provided by IUCN (Justin Moat, Royal Botanic Garden Kew) allowed the calculation of the Extent Of Occurrence (EOO) and the Area Of Occupancy (AOO). The cell area was always set to the largest permissible value which is just under $10 \mathrm{~km}^{2}$ (cell width $=3.16 \mathrm{~km}$ ). Setting a cell size width of $3.2 \mathrm{~km}$ or larger will not allow any taxa to be listed as Critically

(c) 2010 Nationaal Herbarium Nederland

You are free to share - to copy, distribute and transmit the work, under the following conditions:

Attribution: You must attribute the work in the manner specified by the author or licensor (but not in any way that suggests that they endorse you or your use of the work). 

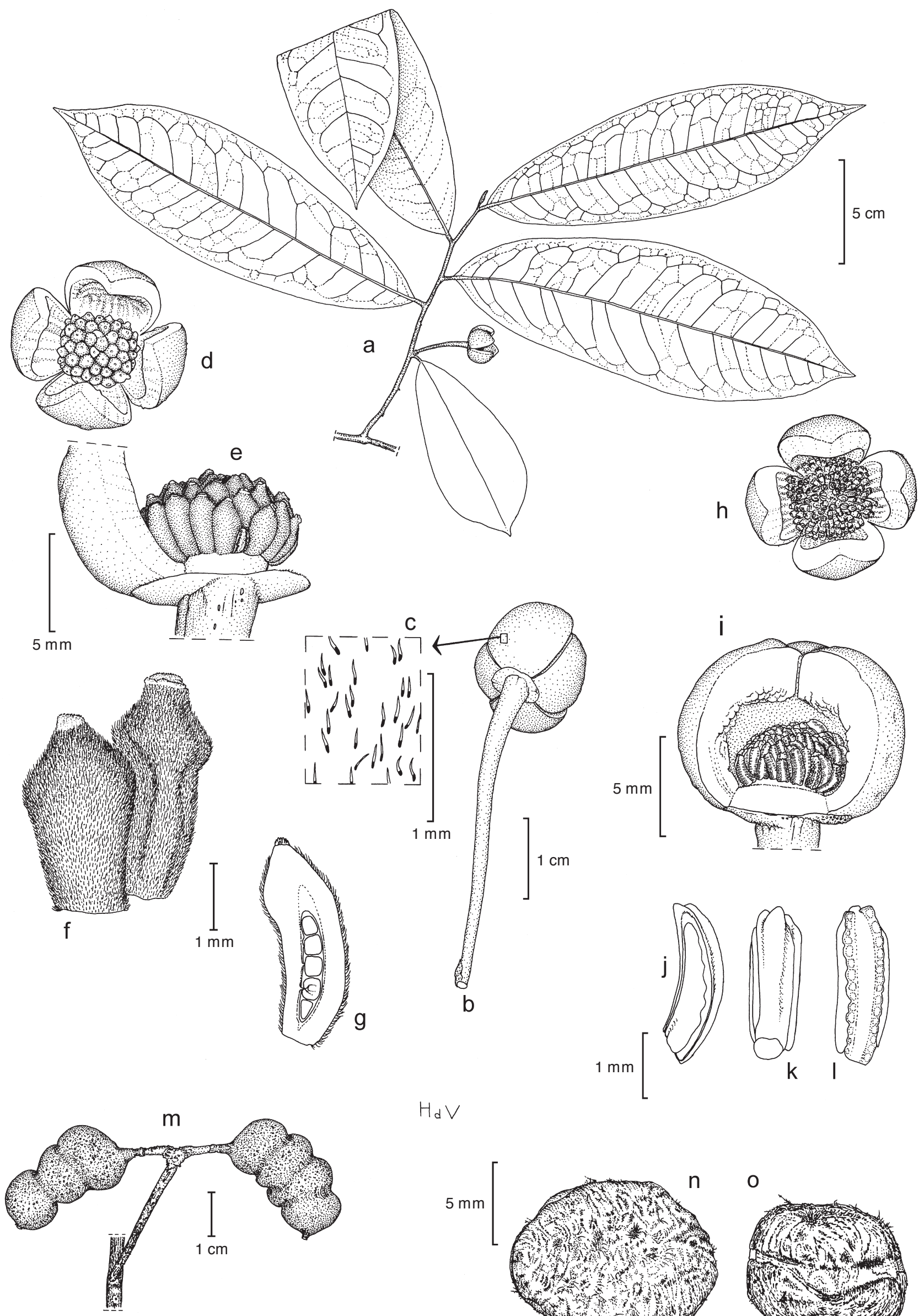

$\mathrm{HdV}$
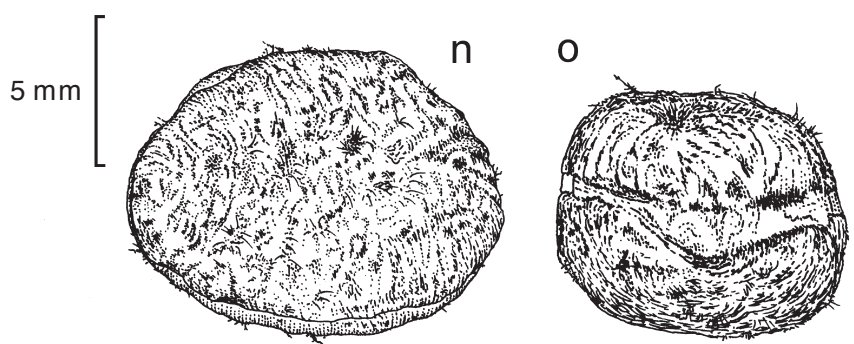

Fig. 1 Uvariopisis lovettiana. a. Flowering branch; b. male flower; c. detail of indumentum; d. female flower, top view; e. detail of female flower with three petals removed; f. details of two carpels; g. longitudinal section of carpel showing uniseriate ovules; h. male flower, top view; i. detail of male flower with one petal removed; j-I. stamen, lateral, back and front view respectively; m. fruits; n. seed, top view; o. seed side view showing hilum (from Couvreur \& F. Mbago 97b (WAG) except fruits from W.R.Q. Luke, T. Butynski, C. Ehardt, T. Jones 10369 (MO)). - Drawing by Hans de Vries. 
Endangered where the threshold $\mathrm{AOO}$ under criterion $\mathrm{B}$ is 10 $\mathrm{km}^{2}$ (Standards and Petitions Working Group 2006).

\section{DESCRIPTION}

Uvariopsis lovettiana Couvreur \& Q. Luke, sp. nov. - Fig. 1,2

Haec species Uvariopsidi bisexuali Verdc. simillima, sed ab ea pedicello sub anthesi $3-5 \mathrm{~cm}$ longo, petalis crassis ovatis, flore femineo ad basem carpellorum staminibus paucis tantum praedito atque ovulis uniseriatis in quoque carpello 4 vel 5 distinguitur. - Typus: T.L.P. Couvreur $97 b$ \& F. Mbago (holo WAG; iso DSM, MO), Tanzania, Morogoro, Iringa District, East Udzungwa National Park, Mwanihana hill, 1400 m, $7^{\circ} 48.5^{\prime} \mathrm{S}, 36^{\circ} 49.4^{\prime} \mathrm{E}, 30$ November 2006.

Monoecious tree 3-7 m tall, dbh 7-30 cm. Young branches sparsely covered with short appressed hairs. Leaves 15-28 by $4.5-7 \mathrm{~cm}$, length : width ratio $3-3.6$, narrowly elliptic, base acute, apex acute to acuminate, acumen $0.5-1 \mathrm{~cm}$ long, glabrous, coriaceous, dark green above, lighter green below; midrib sunken above, raised below; sparsely appressedpubescent when young, the hairs rapidly disappearing with age, secondary veins 11-14, moderately curved upwards, looped towards margin, glabrous on both sides; tertiary venation reticulate. Male and female flowers borne on leafy branches (no cauliflory observed), axillary, single. Flowering pedicels $3-5 \mathrm{~cm}$ long, 2-3 mm diam, sparsely puberulous, green. Bract basal, 1 by $1 \mathrm{~mm}$, covered with short erect hairs. Hairs of flowers with conspicuously dark red base and translucent apex. Sepals 2 , $2-3$ by $4-5 \mathrm{~mm}$, length : width ratio $0.5-0.6$, depressed ovate, base fused, apex rounded, densely appressed-pubescent hairs outside, sparsely so inside, green. Petals 4 , free, in one whorl, $12-15$ by $8-10 \mathrm{~mm}, 2-3 \mathrm{~mm}$ thick, length : width ratio 1.5 , ovate, base truncate, apex acute, coriaceous, sparsely appressed-pubescent outside, glabrous inside, light green outside, white inside. Male and female receptacle globose, c. 5 $\mathrm{mm}$ diam. Female flowers with numerous tightly packed carpels; these $2.5-3$ by c. $1 \mathrm{~mm}$, densely appressed-pubescent; ovules 4 or 5 , uniseriate; stigma $0.2 \mathrm{~mm}$ diam, sessile, glabrous; with 1-5 fertile minute stamens of c. $1 \mathrm{~mm}$ long present at the base of receptacle. Male flowers with numerous stamens, c. 2 $\mathrm{mm}$ long, apex of connective not prolonged. Fruiting pedicels 3-3.5 cm long, 2-2.5 mm diam, sparsely appressed-puberulous. Monocarps 2-4, 2.5-3 cm long, $1-1.5 \mathrm{~cm}$ diam, oblong, markedly constricted between seeds in dried material, glossy yellow turning orange red at maturity, very sparsely puberulous; stipe c. $1 \mathrm{~cm}$ long, c. $2 \mathrm{~mm}$ diam, sparsely puberulous; apex rounded with the clear presence of the stigma. Seeds 2-4 per monocarp, uniseriate, c. 1.5 by c. $1 \mathrm{~cm}$, c. $8 \mathrm{~mm}$ thick; testa smooth, very thin papery, pealing off, light cream; raphe sunken; hilum c. 4 by $1.5 \mathrm{~mm}$, narrowly elliptical.

Distribution \& Habitat - Uvariopsis lovettiana is endemic to the Eastern Arc Mountains of Tanzania, most collections coming from the Udzungwa Mountains National Park and two from the West Usambara Mountains. It mainly grows on rocky soils in wet submontane forests between 1300 and $1700 \mathrm{~m}$ altitude.

Associated species recorded with Uvariopsis lovettiana.

DW Thomas 3921 - Aframomum laxiflorum Lock; Agarista salicifolia (Lam.) G.Don; Alsodeiopsis schumannii (Engl.) Engl.; Coffea mufindiensis Bridson ssp. mufindiensis; Crotonogynopsis usambarica Pax; Cyperus pseudoleptocladus Kuek.; Diospyros whyteana (Hiern) F.White; Drypetes sp. aff. arguta (Müll.Arg) Hutch.; Duhaldea stuhlmannii (O.Hoffm.) Anderb.; Garcinia kingaensis Engl.; Garcinia volkensii Engl.; Lijndenia brenanii (A.Fern. \& R.Fern.) Jacq.-Fel.; Ochna afzelioides N.Robson; Ocotea kenyensis

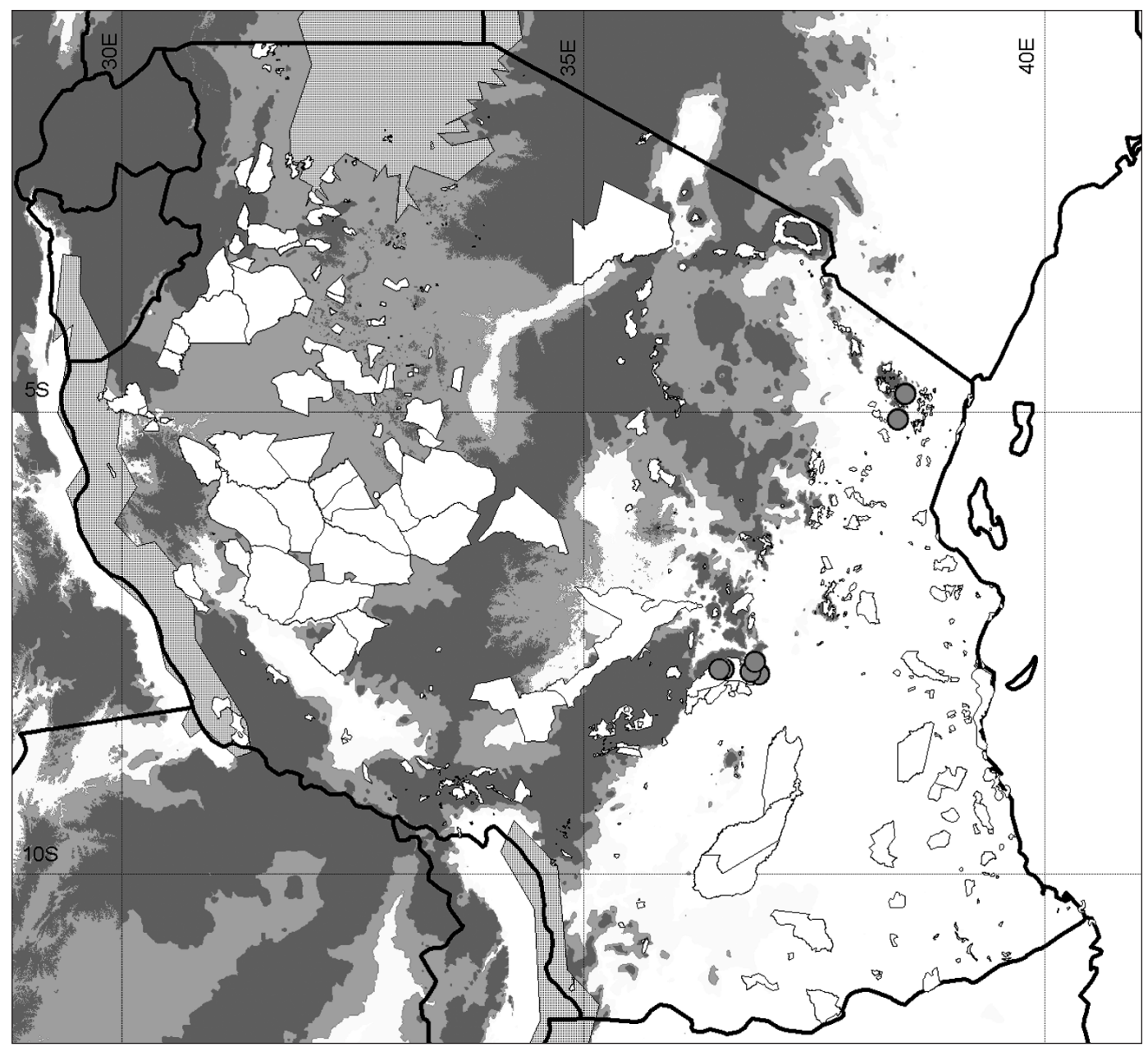

Fig. 2 Distribution of Uvariopsis lovettiana. Grey scale represents altitude: white: 0-800 m; light grey: 800-1000; grey: 1000-1200; dark grey: > 1200 m; white polygons represent borders of protected areas in Tanzania. 
(Chiov.) Robyns \& R.Wilczek; Pauridiantha coalescens Ntome \& Dessein; Psychotria megalopus Verdc.; Saintpauliopsis lebrunii Staner; Sclerochiton glandulosissimus Vollesen; Solanecio epidendricus (Mattf.) C.Jeffrey; Tiliacora funifera (Miers) Oliv.; Vepris nobilis (Delile) Mziray.

Luke 6722 - Craibia brevicaudata (Vatke) Dunn ssp. schliebenii (Harms) J.B.Gillett; Craterispermum longipedunculatum Verdc.; Dicliptera laxata C.B.Clarke; Isolona heinsenii Engl. \& Diels; Isolona linearis Couvreur; Justicia asystasioides (Lindau) M.E.Steiner; Monodora globiflora Couvreur; Plectranthus alboviolaceus Guerke; Pyrostria uzungwaensis Bridson; Rytigynia bugoyensis (K.Krause) Verdc. ssp. glabriflora Verdc.; Rytigynia lichenoxenos (K.Schum.); Rytigynia pseudolongicaudata Verdc.; Vernonia calvoana (Hook.f.) Hook.f. ssp. leucocalyx (O.Hoffm.) C.Jeffrey; Vernonia pteropoda Oliv. \& Hiern.

Luke 7730 - Acmella caulirhiza Delile; Aeschynomene schimperi A.Rich.; Ammannia prieuriana Guill. \& Perr.; Carvalhoa campanulata K.Schum.; Celosia schweinfurthiana Schinz; Chamaecrista telfairiana (Hook.f.) Lock; Cyathula uncinulata (Schrad.) Schinz; Dracaena steudneri Engl.; Erythrococca ulugurensis Radcl.-Sm.; Fleroya rubrostiputata (K.Schum.) Y.F.Deng; Ipomoea wightii (Wall.) Choisy var. obtusisepala Verdc.; Kalanchoe sp. aff. crenata (Andrews) Haw.; Plectranthus trullatus A.J.Paton; Polygonum setulosum A.Rich.; Psychotria cryptogrammata E.M.A.Petit; Pycreus mundtii Nees; Sclerochiton glandulosissimus Vollesen; Sida rhombifolia L.; Solanum giganteum Jacq.; Solanum indicum L.; Sphaeranthus suaveolens (Forssk.) DC.

Luke 10369 - Chlorophytum pusillum Baker; Clerodendrum cephalanthum Oliv. ssp. swynnertonii (S.Moore) Verdc. var. schliebenii (Mildbr.) Verdc.; Craterispermum longipedunculatum Verdc.; Justicia sp. nov. aff. Inaequifolia; Lasiodiscus usambarensis Engl.; Metarungia pubinervia (T.Anderson) C.Baden; Monanthotaxis schweinfurthii (Engl. \& Diels) Verdc.; Pavetta nitidissima Bridson; Plectranthus leptophyllus (Baker) A.J.Paton; Polyceratocarpus scheffleri Engl. \& Diels; Rinorea angustifolia (Thouars) Baill. ssp. ardisiiflora (Oliv.) Grey-Wilson; Rytigynia lichenoxenos (K.Schum.) Robyns ssp. glabrituba Verdc.; Sclerochiton obtusisepalus C.B.Clarke; Vernonia calvoana (Hook.f.) Hook.f. ssp. leucocalyx (O.Hoffm.) C.Jeffrey; Vernonia luhomeroensis Q.Luke \& Beentje; Vernonia sp. nr. pteropoda Oliv. \& Hiern.

Festo 2014 - Chassalia sp. cf. subochreata (De Wild.) Robyns; Clerodendrum cephalanthum Oliv. ssp. swynnertonii (S.Moore) Verdc. var. schliebenii (Mildbr.) Verdc.; Coffea mufindiensis Bridson ssp. Mufindiensis; Cola stelechantha Brenan; Crotonogynopsis usambarica Pax; Erythrococca sanjensis Radcl.-Sm.; Gravesia riparia A.Fern. \& R.Fern.; Heinsenia diervilleoides K.Schum. ssp. Diervilleoides; Lagynias rufescens (E.A.Bruce) Verdc. ssp. angustiloba Verdc.; Leptonychia usambarensis K.Schum.; Mimulopsis solmsii Schweinf.; Pauridiantha paucinervis (Hiern) Bremek. ssp. holstii (K.Schum.) Verdc.; Pavetta lynesii Bridson; Peperomia rotundifolia (L.) Kunth; Psychotria megalopus Verdc.; Rytigynia pseudolongicaudata Verdc.; Sclerochiton glandulosissimus Vollesen; Streptocarpus inflatus B.L.Burtt; Tiliacora funifera (Miers) Oliv.; Vernonia holstii O.Hoffm. vel. sp. aff.; Zanthoxylum deremense (Engl.) Kokwaro.

Phenology - Mature flowers collected end October and in November. Mature and immature fruits collected in November.

Etymology - This species is named in honour of Jon Lovett (University of York, UK) for his pioneering work towards the recognition and conservation of the Eastern Arc Mountains.

ICUN Conservation status - NT. Uvariopsis lovettiana is represented by a fairly low number of herbarium specimens to date, representing just 7 localities with an AOO of c. $70 \mathrm{~km}^{2}$ and an EOO of c. $9700 \mathrm{~km}^{2}$. Under the AOO with just 7 localities, U. lovettiana would qualify for the 'endangered' category. However, the Udzungwa Mountains National Park is a well protected region with the central part hard to access. In 2006, the first author located over 30 mature individuals on Mwanihana hill generally dominating the understorey forest indicating no obvious continuous decline of that existing population. As indicated above, the Udzungwa Mountains are poorly collected, and we would expect the values of AOO, EOO and number of localities to increase (and not decline) in the future with additional collections or identification of existing collections form different herbaria that we have not had on loan (e.g. NHT). We thus consider that the category 'Near Threatened' is appropriate for now.
Additional specimens examined. TANZANIA, B.J. Harris 6257 (EA), Tanga region, T3, West Usambara Mountains, Mwazumbai, 6 April 1972; D.W. Thomas 3921 (EA, MO), Iringa region, Mwanihana Forest Reserve, above Sanje village, forest on steep slope with small streams and swamps, and patches of elfin forest on ridge top, 10 October 1984; W.R.Q. \& P.A. Luke 5084 (EA, K), Iringa region, Udzungwa Mountains National Park (UMNP), Sonjo - Mwanihana Route, 8 November 1997; C.J. Kayombo 1406 (MO), Tanga region, Forest Reserve $5 \mathrm{~km}$ W of Ambangulu Tea Factory above Estate road to Makunga. 3 November 1998. W.R.Q. Luke, B. Bytebier, T. Butynski, C. Ehardt, A. Perkins, G. Kimaro 6722 (BR, EA, K, MO, NHT, US), Iringa region, UMNP, Mt Luhomero Pt 129-131, 27 September 2000; W.R.Q. Luke, R. Mwangulango, T. Butynski, C. Ehardt, J. Kingdon, G. Kimaro 7730 (EA, K, NHT), Tanzania, Iringa region, UMNP, Pt 211, 23 September 2001; W.R.Q. Luke 7842 (EA, K), Iringa region, UMNP, Below Camp 212, 26 September 2001; W.R.Q. \& P.A. Luke, A. Mtui, T. Jones, F. Rovero, G. Laizer 9195 (EA, K), Tanzania, Iringa region, UMNP, Pt 370-371, 16 October 2002; W.R.Q. Luke, T. Butynski, C. Ehardt, T. Jones 10369 (EA, K, MO, NHT), Iringa region, Ndundulu Forest Reserve, Camp 589 - Camp 590, 6 September 2004; L. Festo, M.A. Mwangoka, C.A. Manongi, W.R.Q. Luke 2014 (EA, K, MO, NHT), Iringa region, Udzungwa forest, c. $10 \mathrm{~km}$ from Msolwa village at source of Msolwa stream, 24 October 2005.

\section{DISCUSSION}

Within Uvariopsis two main groups can be distinguished (Kenfack et al. 2003): species in which the male flowers are strictly cauliflorous (a state that concerns the majority of taxa), and species in which the male flowers are strictly axillary or ramiflorous (six species). Uvariopsis lovettiana belongs to the latter group. Morphologically the new species is most similar to $U$. bisexualis, the only other Uvariopsis species occurring in Tanzania and endemic to the Udzungwa Mountains (Couvreur et al. 2006). However, they are clearly differentiated by a number of morphological characters as presented in Table 1. The most obvious one is the occurrence of male and female flowers in $U$. lovettiana, while in $U$. bisexualis the flowers are bisexual (Verdcourt 1971, Kenfack et al. 2003). As indicated above, the majority of species within Uvariopsis are monoecious. Monoecy in $U$. lovettiana is, however, not perfect because a few inconspicuous stamens (1-5, Fig. 1e), smaller than in male flowers but fertile, can be found at the base of the receptacle within the female flowers. A few such stamens in female flowers were also observed in the West African species U. globiflora (Jongkind $1804, \mathrm{WAG}$ ), although they are not mentioned in the protologue by Keay (1952). These species are, strictly speaking, androdioecious (male and bisexual flowers). However, because the few small stamens occurring in the bisexual flowers probably play no significant role in reproduction, we consider these flowers as functionally female. This point of view was apparently also adopted by Verdcourt (1971: 69) who noted the presence of these few stamens in female flowers, but nevertheless considered Uvariopsis as monoecious. It is unclear up to now how many other species exhibit this character. In $U$. bisexualis the stamens are numerous and present in many rows topped by six carpels (Verdcourt 1986), providing little doubt about the true bisexual nature of this species.

One other strikingly different character between the two species is the number and disposition of ovules. Uvariopsis is characterized by a biseriate placentation (Le Thomas 1969, Verdcourt 1971). In U. lovettiana, however, the ovules are uniseriate which is to our knowledge unique within the genus. Uvariopsis bisexualis is also characterized by a large number of ovules per carpel (22-24) while $U$. lovettiana has only 4 or 5 per carpel. Finally, these characters related to the carpels allowed us to identify the fruiting specimens belonging to $U$. lovettiana, in that the seeds were uniseriate and few in numbers per monocarp (1-3). 
Table 1 Principal morphological differences between Uvariopsis lovettiana and $U$. bisexualis.

\begin{tabular}{lll}
\hline Character & U. lovettiana & U. bisexualis \\
\hline petal shape & ovate & narrowly oblong \\
sex distribution & monoecious & bisexual \\
flowering pedicel length & $3-5 \mathrm{~cm}$ & $1.2-1.5 \mathrm{~cm}$ \\
ovule arrangement & uniseriate & biseriate \\
ovule number & 4 or 5 & $22-24$ \\
\hline
\end{tabular}

The main centre of distribution of $U$. lovettiana is found in the Udzungwa Mountains. However, two specimens have been identified from the West Usambaras, in north-eastern Tanzania (Fig. 2). Disjunct distributions between the Udzungwa and Usambara Mountains is a common pattern for Eastern Arc endemics (Lovett 1993, Burgess et al. 2007), and can also be found in other Annonaceae species such as Isolona heinsenii Engl., I. linearis Couvreur and Polyceratocarpus scheffleri Engl. \& Diels (Couvreur 2009).

Acknowledgements Jan Wieringa (WAG) is thanked for discussions on nomenclature and databasing of specimens. We thank Roy Gereau (MO) for the latin diagnosis, discussions concerning this new species and sending the MO material on loan. Hans de Vries is thanked for the botanical illustrations. We appreciate the input of Marc Sosef (WAG) and James Richardson (E) for critically reading earlier versions of the manuscript. Frank Mbago from the University of Dar es Salaam is deeply thanked for help and assistance while in the field in 2006. Funding for fieldwork for TLPC came from the Netherlands Organization for Scientific Research (NWO), Alberta Mennega Stichting, Hugo de Vries Fonds and Air France-KLM. WRQL wishes to thank Tom Butynski and Carolyn Ehardt and the Margot Marsh Biodiversity Foundation for funding many of his collecting trips in the Udzungwa Mountains National Park. Special thanks go to Herman Mgweni, Director, WWF Tanzania, for arranging permission to carry out plant surveys in the Park.

\section{REFERENCES}

Burgess ND, Butynski TM, Cordeiro NJ, Doggart NH, Fjeldsa J, Howell KM, Kilahama FB, Loader SP, Lovett JC, Mbilinyi B, Menegon M, Moyer DC, Nashanda E, Perkin A, Rovero F, Stanley WT, Stuart SN. 2007. The biological importance of the Eastern Arc Mountains of Tanzania and Kenya. Biological Conservation 134: 209-231.

Chatrou LW, Rainer H, Maas JM. 2004. Annonaceae. In: Smith N, Mori SA, Henderson A, Stevenson DW, Heald SV (eds), Flowering plants of the Neotropics: 18-20. Princeton University Press, Princeton.

Couvreur TLP. 2009. Monograph of the African genera Isolona and Monodora (Annonaceae). Systematic Botany Monographs 87: 1-150.

Couvreur TLP, Gereau RE, Wieringa JJ, Richardson JE. 2006. Description of four new species of Monodora and Isolona (Annonaceae) from Tanzania and an overview of Tanzanian Annonaceae diversity. Adansonia 28: $243-266$.
Couvreur TLP, Richardson JE, Sosef MSM, Erkens RHJ, Chatrou LW. 2008. Evolution of syncarpy and other morphological characters in African Annonaceae: a posterior mapping approach. Molecular Phylogenetics and Evolution 47: 302-318.

ESRI. 2002. ArcView GIS TM.

Jones T, Ehardt CL, Butynski TM, Davenport TRB, Mpunga NE, Machaga SJ, De Luca DW. 2005. The highland mangabey Lophocebus kipunji: A new species of African monkey. Science 308: 1161-1164.

Keay RWJ. 1952. Revision of the "Flora of West Tropical Africa", I - Annonaceae. Kew Bulletin 7: 149-157.

Kenfack D, Goseline G, Gereau RE, Schatz GE. 2003. The genus Uvariopsis (Annonaceae) in tropical Africa with a recombination and one new species from Cameroon. Novon 13: 443-449.

Knox EB, Luke WRQ, Thulin M. 2004. A new giant Lobelia from the Eastern Arc Mountains, Tanzania. Kew Bulletin 59: 189-194.

Le Thomas A. 1969. Annonacées. In: Aubréville A (ed), Flore du Gabon: 1-371. Muséum National d'Histoire Naturelle, Paris.

Lovett JC. 1993. Eastern Arc moist forest flora. In: Lovett JC, Wasser SK (eds), Biogeography and ecology of the rain forests of eastern Africa: 33-55. Cambridge University Press, Cambridge.

Luke Q, Deroin T. 2005. A new Toussaintia (Annonaceae) from Tanzania. Journal of the East Africa Natural History Society and National Museum 94: 165-174.

Luke QWR, Beentje HJ. 2003. A new Vernonia (Compositae: Vernonieae) from the Udzungwa Mountains, Tanzania. Kew Bulletin 58: 977-980.

Myers N, Mittermeier RA, Mittermeier CG, Da Fonseca GAB, Kent J. 2000. Biodiversity hotspots for conservation priorities. Nature 403: 853-858.

Richardson JE, Chatrou LW, Mols JB, Erkens RHJ, Pirie MD. 2004. Historical biogeography of two cosmopolitan families of flowering plants: Annonaceae and Rhamnaceae. Philosophical Transactions of the Royal Society of London, Series B 359: 1495-1508.

Rovero F, Rathbun GB, Perkin A, Jones T, Ribble DO, Leonard C, Mwakisoma RR, Doggart N. 2008. A new species of giant sengi or elephant-shrew (genus Rhynchocyon) highlights the exceptional biodiversity of the Udzungwa Mountains of Tanzania. Journal of Zoology 274: 126-133.

Schatz GE. 2002. Taxonomy and herbaria in service of plant conservation: Lessons from Madagascar's endemic families. Annals of the Missouri Botanical Garden 89: 145-152.

Standards and Petitions Working Group. 2006. Guidelines for Using the IUCN Red List Categories and Criteria. Version 6.2. Prepared by the Standards and Petitions Working Group of the IUCN SSC Biodiversity Assessments Sub-Committee in December 2006. Downloadable from http://www.iucnredlist.org/.

Van Heusden ECH. 1992. Flowers of Annonaceae: morphology, classification, and evolution. Blumea Supplement 7: 1-218.

Verdcourt B. 1971. Annonaceae. In: Milne-Redhead E, Polhill RM (eds), Flora of Tropical East Africa: 1-131. Crown Agents for Oversea Governments and Administrations, London.

Verdcourt B. 1986. New taxa of East African Annonaceae. Kew Bulletin 41: 287-297.

Verdcourt B. 2003. Emphysetes udzungwensis, a most remarkable new genus and species of slug from the Udzungwa Mountains in southern Tanzania (Gastropoda, Pulmonata, Urocyclidae). Basteria 67: 107-111.

Willis F, Moat J, Paton A. 2003. Defining a role for herbarium data in Red List assessments: a case study of Plectranthus from eastern and southern tropical Africa. Biodiversity and Conservation 12: 1537-1552. 